\title{
THE HIGH-TEMPERATURE TRIBOLOGY OF IRON MATRIX HYPOEUTECTIC ALLOY AFTER UNDER-ANNEALING NORMALIZING
}

\section{INTRODUCTION}

An example of adamite cast steel [1-4] is G200CrNiMo4-3-3 cast steel which is widely used for tools that are used in metallurgy. Tests of this cast steel $[1,5,6]$ confirm its great potential as a material for working mill rolls. It is characterized by good resistance to thermal fatigue, as well as wear resistance. It was found, however, that the microstructure of G200CrNiMo4-3-3 cast steel, just after casting, is not optimal in terms of mechanical properties and fracture toughness [7-12].

Microstructure modification of this material is done on the way of heat treatment by socalled under-annealing normalization [7,8]. It allows to improve mechanical properties by obtaining of appropriate morphology of carbide precipitates [7]. On the basis of so far carried studies of wear mill rolls [13-15] made of G200CrNiMo4-3-3 cast steel as well as laboratory tests [16-20] it was found that the mechanism of wear is strongly dependent on carbides morphology.

During hot processing in surface layer of mill rolls made of G200CrNiMo4-3-3 cast steel a change of matrix takes place in the structure from pearlitic to austenitic, what may alter the influence of secondary carbides morphology and ledeburite on tribological properties. Thus, within the frames of this work the tribological tests of G200CrNiMo4-3-3 cast steel were carried out at the temperature that guaranteed the presence of austenitic matrix.

\section{TEST MATERIALS}

Test material was high-carbon G200CrNiMo4-3-3 cast steel of ledeburite class with chemical composition presented in Table 1.

* Ph.D., ** M.Sc.: Faculty of Metals Engineering and Industrial Computer Sciences, AGH University of Science and Technology, Kraków, Poland; jkrawczy@metal.agh.edu.pl 
Table 1. Chemical composition (weight \%) of G200CrNiMo4-3-3 cast steel

\begin{tabular}{|c|c|c|c|c|c|c|c|c||}
\hline $\mathrm{C}$ & $\mathrm{Mn}$ & $\mathrm{Si}$ & $\mathrm{P}$ & $\mathrm{S}$ & $\mathrm{Cr}$ & $\mathrm{Ni}$ & $\mathrm{Mo}$ & $\mathrm{Fe}$ \\
\hline 1.97 & 0.60 & 0.65 & 0.053 & 0.006 & 1.01 & 0.75 & 0.28 & rest \\
\hline
\end{tabular}

Based on testing of kinetics of phase transformations of super-cooled austenite, quenching series and metallographic analysis [7] a heat treatment was applied that consisted of heating of G200CrNiMo4-3-3 cast steel samples to four annealing temperatures: $\mathrm{T}_{\mathrm{A}}=850,900,950$ and $1050^{\circ} \mathrm{C}$, maintaining them for 10 hours and cooling at constant rate of $48^{\circ} \mathrm{C} / \mathrm{h}$ to room temperature. Figure 1 presents microstructures of test cast steel after mentioned above variants of under-annealing normalization.

a)

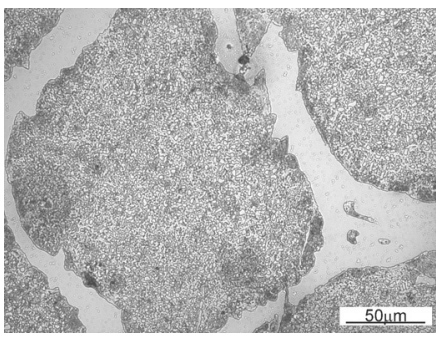

c)

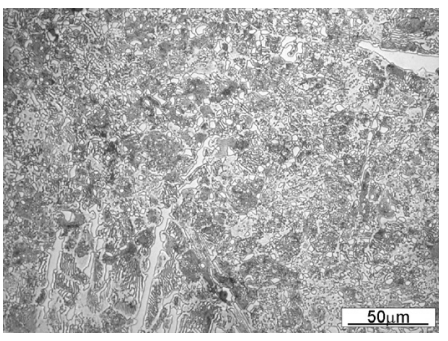

b)

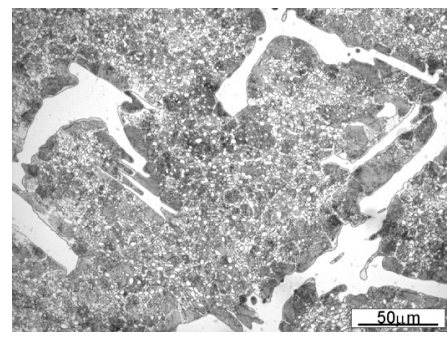

d)

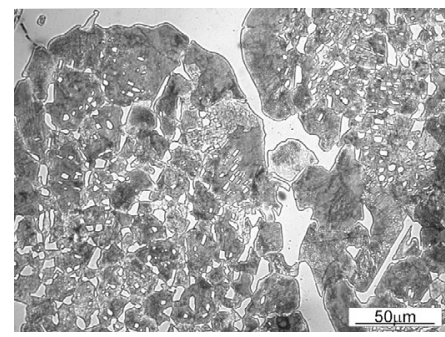

Fig. 1. Microstructure of G200CrNiMo4-3-3 cast steel after heat treatment: a) $T_{A}=850^{\circ} \mathrm{C}$; b) $T_{A}=900^{\circ} \mathrm{C}$; c) $T_{A}=950^{\circ} \mathrm{C}$; d) $T_{A}=1050^{\circ} \mathrm{C}$. Etched with $2 \%$ nital

As one may notice, along with rising annealing temperature there are „sub-grains” being created in microstructure of G200CrMoNi4-3-3 cast steel, boundaries of which are made of partially coagulated secondary cementite ,transported” there (inside of grains) from boundaries of primary austenite grains. Only austenitizing temperature of $850^{\circ} \mathrm{C}$ turned out to be too low to create a net of cementite "sub-grains". At this temperature the coagulated precipitations of secondary cementite are noticeable inside of primary austenite grains. A distinct net inside of primary austenite grain is being created after austenitizing at $900^{\circ} \mathrm{C}$.

\section{TESTING METHODOLOGY}

Microstructures and tribilogically used surfaces were subjected to metallographic testing.

Tribological tests were conducted under load of $10 \mathrm{~N}$ and at the temperature of $750^{\circ} \mathrm{C}$ using T-21 testing machine (Fig. 2a) applying tribological contact scheme of friction pin on 
disc type (Fig. 2b). As a counter-samples the friction discs made of 100Cr6 bearing steel, heat treated in order to receive the highest hardness, were used. During the test a continuous sampling of friction factor was made.
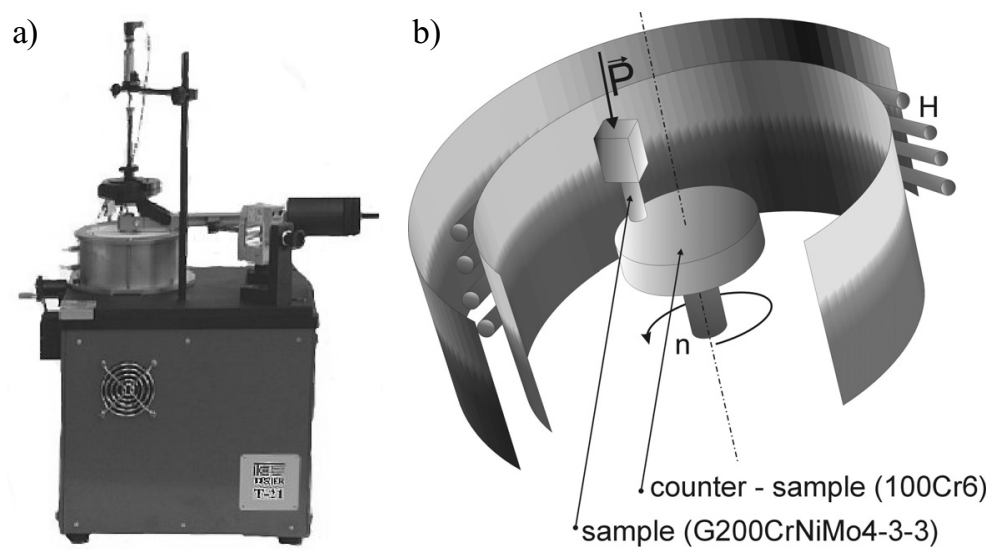

Fig. 2. Laboratory stand for the tribological tests: a) T-21 testing equipment; b) tribological contact scheme

\section{TESTING OF TRIBOLOGICAL WEAR}

Abrasive wear during the test was continuously measured and defined as decrease of distance between grips of sample and counter-sample. Therefore it is a sum of sample and counter-sample wear and it is named as linear wear.

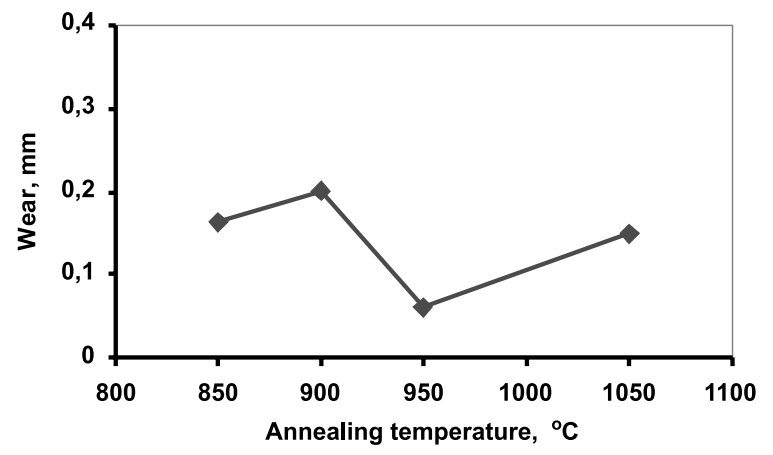

Fig. 3. Dependence of wear from annealing temperature for a load of $10 \mathrm{~N}$, time $2900 \mathrm{~s}$, distance $290 \mathrm{~m}$ at the temperature of $750^{\circ} \mathrm{C}$

Linear wear grades as a function of annealing temperature are presented in Figure 3. Analysis of diagram presented in Figure 3 allows to state that the most advantageous tribological conditions from sample and counter-sample wear point of view correspond to annealing temperature of $950^{\circ} \mathrm{C}$. Yet, the least advantageous carbides morphology, from this point of view, was obtained as a result of under-annealing normalization at the temperature of $900^{\circ} \mathrm{C}$. 
It is, most probably, the result of differences in degree of discontinuity of ledeburitic cementite network and the size and morphology of precipitates of secondary cementite. On the basis of the above, one may state, that in order to ensure the least wear of rubbing pair consisting of G200CrNiMo4-3-3 cast steel and bearing steel in present test conditions, the morphology of ledeburitic cementite and secondary cementite should be properly "balanced".

\section{TESTING OF SURFACE LAYER MICROSTRUCTURE}

Figure 4 presents microphotographs of test samples after tribological test on distance of $490 \mathrm{~m}$ conducted under load of $10 \mathrm{~N}$ and at the temperature of $750^{\circ} \mathrm{C}$.

a)

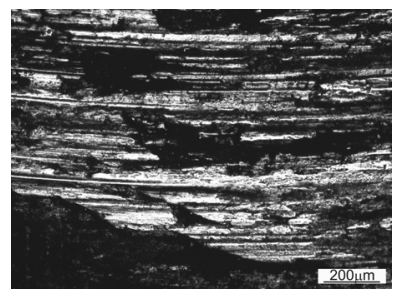

d)

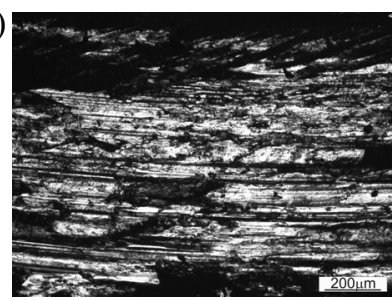

g)

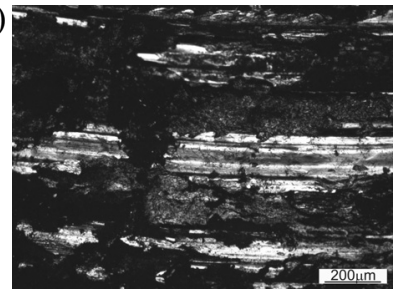

j)

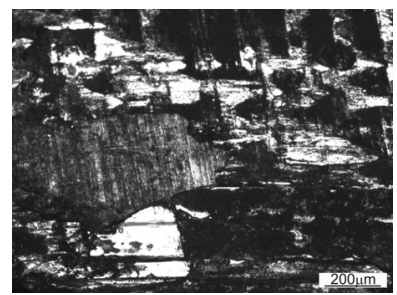

b)

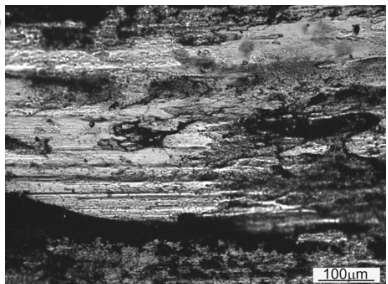

e)
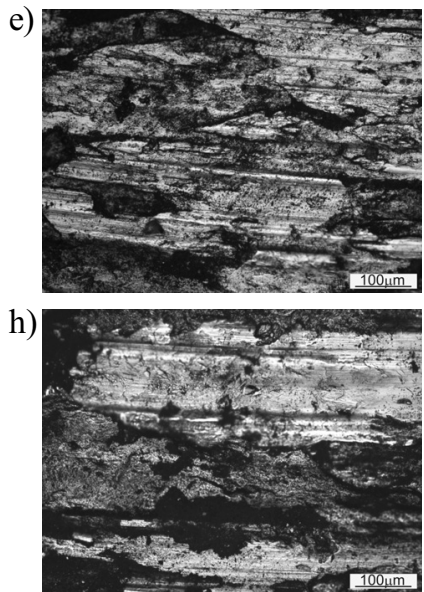

K)

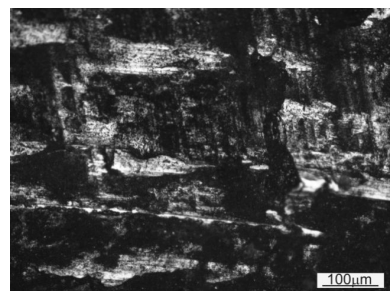

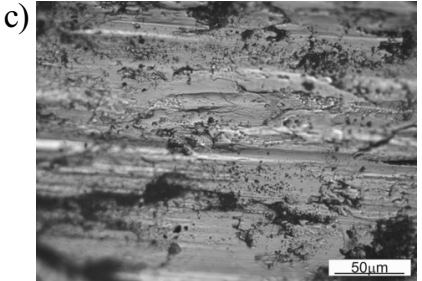

f)

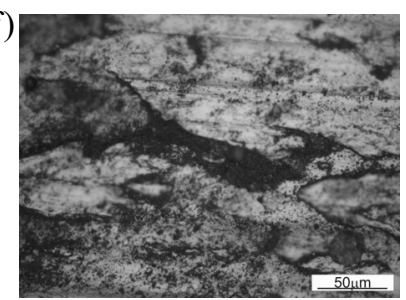

i)
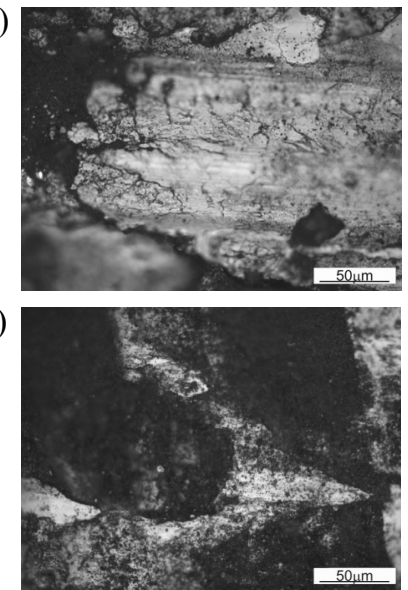

Fig. 4. Surface of investigated samples after tribological testing for $4900 \mathrm{~s}$ and under load of $10 \mathrm{~N}$ and the temperature of $750^{\circ} \mathrm{C}$; a-c) $T_{A}=850^{\circ} \mathrm{C}$; d-f) $T_{A}=900^{\circ} \mathrm{C}$; g-i) $T_{A}=950^{\circ} \mathrm{C}$; j-l) $T_{A}=1050^{\circ} \mathrm{C}$

It is difficult to distinguish the constituents of the microstructure of test cast steel on the surfaces after high-temperature tribological test. Whereas, one may observe the products of 
surface oxidation. Surface development of the samples subjected to high-temperature tribological test, is significantly increasing starting from austenitizing temperature of the sample at $950^{\circ} \mathrm{C}$. In case of the sample austenitized at $1050^{\circ} \mathrm{C}$ there is chipping of large fragments during tribological test clearly visible.

\section{DETERMINATION OF FRICTION FACTOR}

Friction factor was recorded for test duration time from 2000 up to $4900 \mathrm{~s}$, what corresponds to friction distance of 200 to $490 \mathrm{~m}$. Within this range are the most stable conditions of high-temperature tribological test (without grinding in or test ending range).

A set of friction factor changes of samples for high-temperature test within time range from 2000 to $4900 \mathrm{~s}$ (friction distance from $200 \mathrm{do} 490 \mathrm{~m}$ ) is presented in Figure 5. Whereas, a set of average friction factor for individual variant of heat treatment for the same range of test duration of above mentioned tribological test is presented in Figure 6.

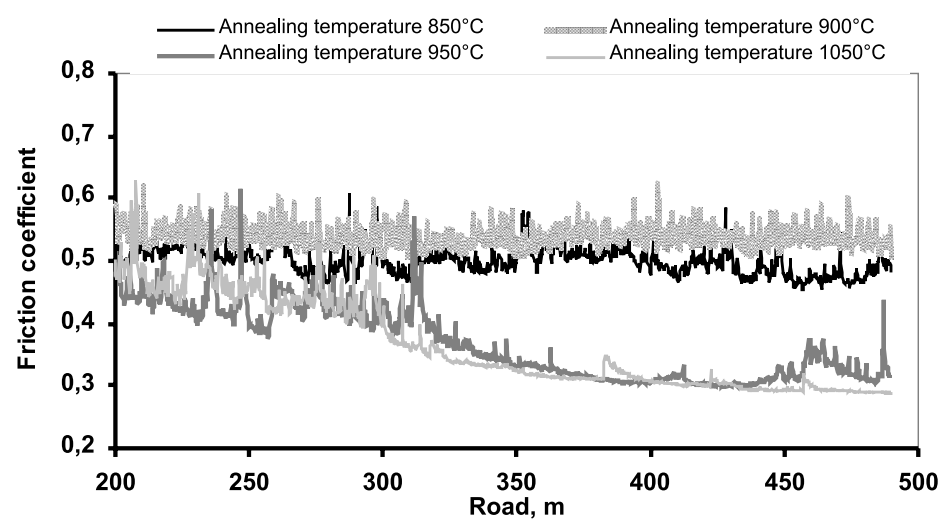

Fig. 5. Diagrams of friction factor changes during tribological tests for the period of $2900 \mathrm{~s}$, and the load of $10 \mathrm{~N}$, and the temperature of $750^{\circ} \mathrm{C}$

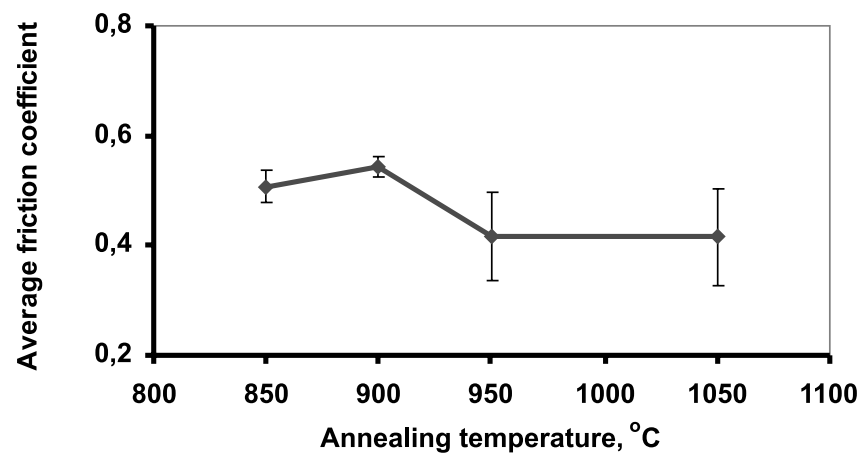

Fig. 6. Average friction factor for individual variant of heat treatment during tribological test for the period of $2900 \mathrm{~s}$ 
One may notice a distinct decrease of friction factor in case of under - annealing normalized samples at the temperature of 950 and $1050^{\circ} \mathrm{C}$ on friction distance of $300 \mathrm{~m}$. Also the amplitude of changes of friction factor was decreasing within this range. It resulted in obtaining during tribological test, for these two variants of heat treatments, the lowest average friction factor (Fig. 6). Therefore one may state that in case of high-temperature tests (when carbides matrix is made of austenite), up to a certain moment, the fragmentation of ledeburitic cementite net and increase of amount of spheroidal precipitates of secondary cementite is leading to increase of friction factor. However, further fragmentation of ledeburitic cementite network and increase of amount of spheroidal precipitates of secondary cementite in high-temperature conditions (austenite in matrix) lowers the friction factor and stabilizes it at the level of about 0.35 .

\section{CONCLUSIONS}

Results obtained in present research allow to formulate the following conclusions:

1. Different morphology of carbides precipitates caused by austenitizing temperature change during under-annealing normalization influences the character of wear, its magnitude and tribological properties of cast steel (friction factor).

2. Austenitizing at the temperature of $950^{\circ} \mathrm{C}$ and higher, during under-annealing normalization, causes that the samples after tribological test are distinguished by significant surface development.

3. The morphology of carbides precipitates obtained for the austenitizing temperature of $1050^{\circ} \mathrm{C}$ fosters chipping, during tribological test, of large fragments of the sample.

4. Creation of secondary cementite along the boundaries of austenite secondary grains favours the mechanism of tribological wear of G200CrNiMo4-3-3 cast steel.

5. In case if, after under-annealing normalization, the network of carbides, precipitated along the boundaries of primary austenite grains, is adequately shattered in the microstructure of G200CrNiMo4-3-3 cast steel, the conditions of tribological wear become stable.

6. The optimal microstructure of tested cast steel from tribological properties point of view, for its application for mill rolls is after under-annealing normalizing at $950^{\circ} \mathrm{C}$.

Research financed by the Ministry of Science and Higher Education, conducted within the frames of own AGH research no. 10.10.110.855.

\section{REFERENCES}

[1] Krawczyk J., Pacyna J.: The role of transformed ledeburite in high temperature tribology on the example of adamite rolls. 11th International Scientific Conference on Contemporary Achievements in Mechanics, Manufacturing and Materials Science, Gliwice - Zakopane 6-9 December 2005, 534-540

[2] http://www.sheffieldforgemasters.com/roll_section.php, 9.09.2005

[3] http://www.hitechimetais.com/products/rolls/cast/documents/AdamiteSteelRolls.pdf, 7.09.2005

[4] http://www.dexinroll.nease.net/dexinCD/HTM/ADAMITE/adamite.htm, 22.07.2005

[5] Krawczyk J., Pacyna J.: Effect of tool microstructure on the white layer formation. J. of Achievements in Materials and Manufacturing Engineering 17, 1-2 (2006), 93-96 
[6] Krawczyk J.: The dependence between thermal expansion coefficient and wear of tools and structural components. Tribologia 212, 2 (2007), 339-352 (in Polish)

[7] Roziniata E.: The role of cementite In fracture toughness of L200HNM cast steel, PhD Thesis, Promotor: J. Pacyna, AGH, Kraków, 2008 (in Polish)

[8] Pacyna J., Roziniata E.: Effect of annealing on structure and properties of ledeburitic cast steel, J. of Achievements in Materials and Manufacturing Engineering 24 (2007), 84-90

[9] Krawczyk J., Pacyna J.: The heat treatment influence on structure and properties of cast steels for mill rolls. Hutnik-Wiadomości Hutnicze 71, 7-8 (2004), 370-374 (in Polish)

[10] Krawczyk J., Pacyna J., Kokosza A.: Fracture toughness of cast materials for mill rolls. Proceedings of the sixth international Conference for Mesomechanics, Multiscaling in Applied Science and Emerging Technology, Fundamentals and Applications in Mesomechanics. Patras, Greece, 31May-4 June 2004, 201-207

[11] Krawczyk J., Roziniata E., Pacyna J.: The influence of hypereutectoid cementite morphology upon fracture toughness of chromium-nickel-molybdenum cast steel of ledeburite class. J. of Materials Processing Technology 162-163 (2005), 336-341

[12] Krawczyk J., Pacyna J., Kokosza A., Mikulski G., Grodowski P.: The cast steels for mill rolls - properties modification. Metalurgia 45 (2005), 80-87 (in Polish)

[13] Krawczyk J., Szymański M.: The influence of thermal expansion coefficient on the thermal cracks formation in the cast steel mill rolls. Konferencja Naukowo-Techniczna Huta Buczek sp. z. o. o., Wisła, Poland, January 2007, s. 32-37 (in Polish)

[14] Pacyna J., Krawczyk J.: The influence of microstructural constituents on the working properties of the working rolls in the hot rolling mill. Konferencja Naukowo - Techniczna Huta Buczek Sp. z. o. o., Wisła, Poland, January 2007, s. 10-12 (in Polish)

[15] Krawczyk J., Pacyna J., Szczygiet A., Latała D.: The role of transformed ledeburite and hypereutectoid cementite morphology on mill roll tribology. XL Konferencja Naukowo - Techniczna Pt. „Tendencje i kierunki rozwoju produkcji walców" Huta Buczek sp. z. o. o., Ustroń - Jaszowiec, marzec 2006, s. 5366 (in Polish)

[16] Dziurka R., Krawczyk J., Rożniata E.: The influence of under-annealing normalizing of ledeburitic cast steel on the mechanism of its tribological wear, Konferencja naukowa z okazji 85-lecia Katedry Metaloznawstwa i Metalurgii Proszków, ed by G. Michta, Kraków, 2007, s. 112-115 (in Polish)

[17] Krawczyk J., Rozniata E., Dziurka R.: The influence of under-annealing normalising of G200CrNiMo43-3 cast steel on its tribological properties, Tribologia 219, 3 (2008), 27-35 (in Polish)

[18] Krawczyk J., Dziurka R., Rożniata E., Madej M.: High- and lowtemperature tribology of alloyed ledeburitic cast steel after under-annealing normalizing. Zeszyty Studenckiego Towarzystwa Naukowego 15 (2008), 119-124 (in Polish)

[19] Krawczyk J., Chaieb S., Madej M.: The role of microstructure in the mechanism of tribological wear of G200CrMoNi4-3-3 cast steel. Zeszyty Studenckiego Towarzystwa Naukowego 13 (2007), 91-98 (in Polish)

[20] Chaieb S., Krawczyk J., Madej M.: The influence of heat treatment on friction coefficient on adamite ledeburitic cast steel - bearing steel contact surface. Konferencja naukowa z okazji 85-lecia Katedry Metaloznawstwa i Metalurgii Proszków, ed by G. Michta, Kraków, 2007, s. 100-103 (in Polish)

Received

December 2008 